\title{
Research on China's Macro-Leverage Ratio and Risk Prevention
}

\author{
Yao Yao ${ }^{1}$, Quanxin Liu² \\ ${ }^{1}$ School of Business Administration, Southwest University of Finance and Economics, Chengdu \\ 611130, China; \\ ${ }^{2}$ School of Electrical and Mechanical Engineering, Nanjing University of Aeronautics and \\ Astronautics, Nanjing 210016, China.
}

\begin{abstract}
Since the financial crisis in 2008, the leverage ratio of China's non-financial enterprises and government departments has been on the rise. Compared with developed countries, China's leverage ratio is not high, but the potential risk is not small. First, there are more hidden liabilities. Second, debt growth is relatively fast. When it comes to deleveraging, we need to clarify the scope of deleveraging and the idea of deleveraging. While controlling the rapid increase in the leverage ratio of the non-financial sector, the leverage ratio of non-financial enterprises, especially stateowned enterprises, was mainly reduced. In this way, we will speed up supply-side structural reform, reform of state-owned enterprises, improve the direct financing mechanism, and standardize the leverage tools and approaches.
\end{abstract}

Keywords: Leverage; non-financial enterprises; potential risks; reform of state-owned enterprises.

\section{Introduction}

In recent years, financial risks have been constantly moving between the stock, real estate, bonds, Internet finance and foreign exchange markets. China's economy has entered a period of high financial risk. [1] [2] The National People's Congress in March 2017 has made prevention and control of systemic financial risks a priority of economic policy. [3] In 2018, China is at a crossroads. On the one hand, we need to get rid of internal leverage, from the financial system to the real economy. The other is the prospect of higher interest rates and tax cuts in us. "Reducing leverage and stabilizing leverage" will be an important task for economic work this year. So, how high is China's macro leverage ratio, how it is formed, what are the potential risks and how to resolve them? China's financial risks have become a major concern for investors and policy makers alike.

\section{Current Situation of China's Macro-Leverage Ratio}

Leverage ratio generally refers to the ratio of equity capital to total assets in the balance sheet. Leverage is a measure of debt risk, reflecting the ability to repay. The "leverage ratio" typically refers to the ratio of capital held by commercial Banks to the balance of assets within and outside the bank after adjustment. [4]. at the micro level, "leverage ratio" generally refers to the number of assets and liabilities of economic entities. At a macro level, the "leverage ratio" can be calculated as the ratio of a country's total debt to its total assets. We can also use the ratio of total debt to GDP, which is the ratio of debt stock to income flow, to measure the sustainability of debt. 


\subsection{Leverage in the Non-Financial Sector}

\section{Leverage ratio of China's non-financial sector}

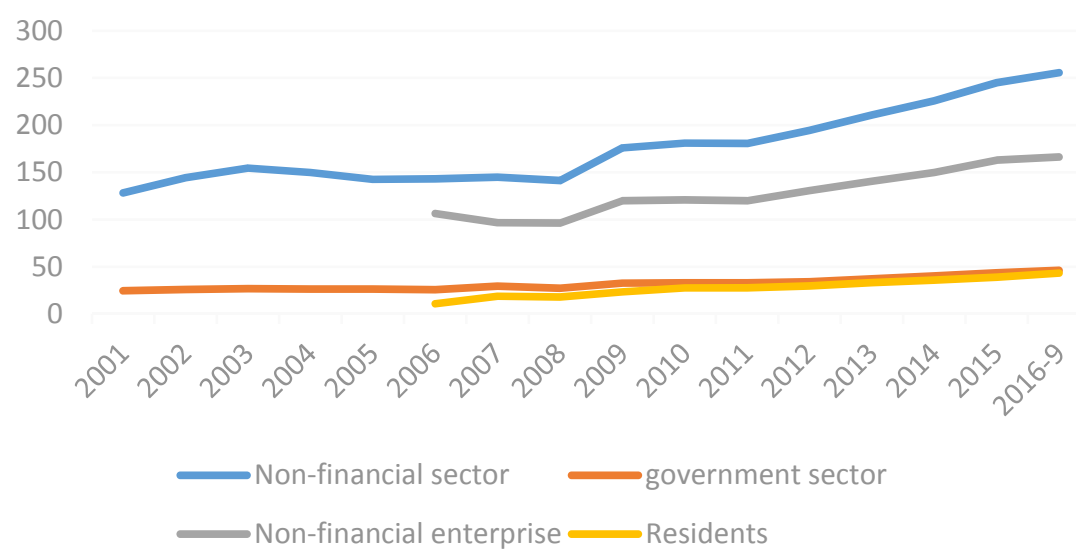

Figure 1. Leverage ratio of China's non-financial sector (Source BIS)

From December 2008 to September 2016, the total leverage ratio of the non-financial sector increased by 114.3 percentage points. Among them, the non-financial enterprise sector rose by 69.9 percentage points, the household sector by 25.3 percentage points and the government sector by 19 percentage points. The non-financial corporate sector saw the biggest increase in leverage, accounting for 61 per cent of total leverage.

\subsection{Leverage Ratio of Government Department}

Government debt is divided into central and local governments. Local government debt can be divided into two parts: local government debt and local government debt. According to the IMF, the leverage ratio of Chinese government departments was $43.9 \%$ in 2015 , up 12.25 percentage points from 2008, far lower than that of Japan, Italy and the United States. Generally speaking, it is at a low level. [5] Compared with other developed countries, China's government debt has three characteristics:

The central government actually assumes the ultimate guarantee obligation. As a country with a single political system, China's local governments do not have a legal basis for bankruptcy due to excessive debts. [6] (2). Under the interaction between the state-owned land property right system and the state-owned banking system, the government debt lacks an effective restraint mechanism. China's local governments borrow money, and financial institutions "dare" to borrow from local governments, based on the special institutional arrangements of local governments to actually exercise urban state-owned land property rights. State-owned land rights mortgage and commercial bank loans are the basic modes of financing and debt of local governments in China. In this model, the fluctuation of land price not only determines the scale of local government financing, but also determines the risk of local government debt. Once land prices fall more, it often leads to significant debt repayment risks. (3). Implicit government debt cannot be ignored. In government debt, different types of debt have different degrees of risk and cannot be simply added up. It is necessary to calculate the probability or present value of the government's contingent debt and hidden debt on the basis of the government's direct debt.

\subsection{Leverage Ratio of Residents}

The debt of the household sector depends mainly on loans. Since households cannot issue individual bonds, the debts of the household sector are all loans. After the 2008 financial crisis, household sector leverage rose rapidly, rising 21.5 percent between 2008 and 2015. Due to the low leverage base of the household sector in China, the leverage of the residential sector in developed countries showed negative growth over the same period, but China was still at a low level. Research shows that the increase in household debt mainly comes from the increase in housing mortgage loans, followed by car loans and credit card loans. 


\subsection{Leverage in the Financial Sector}

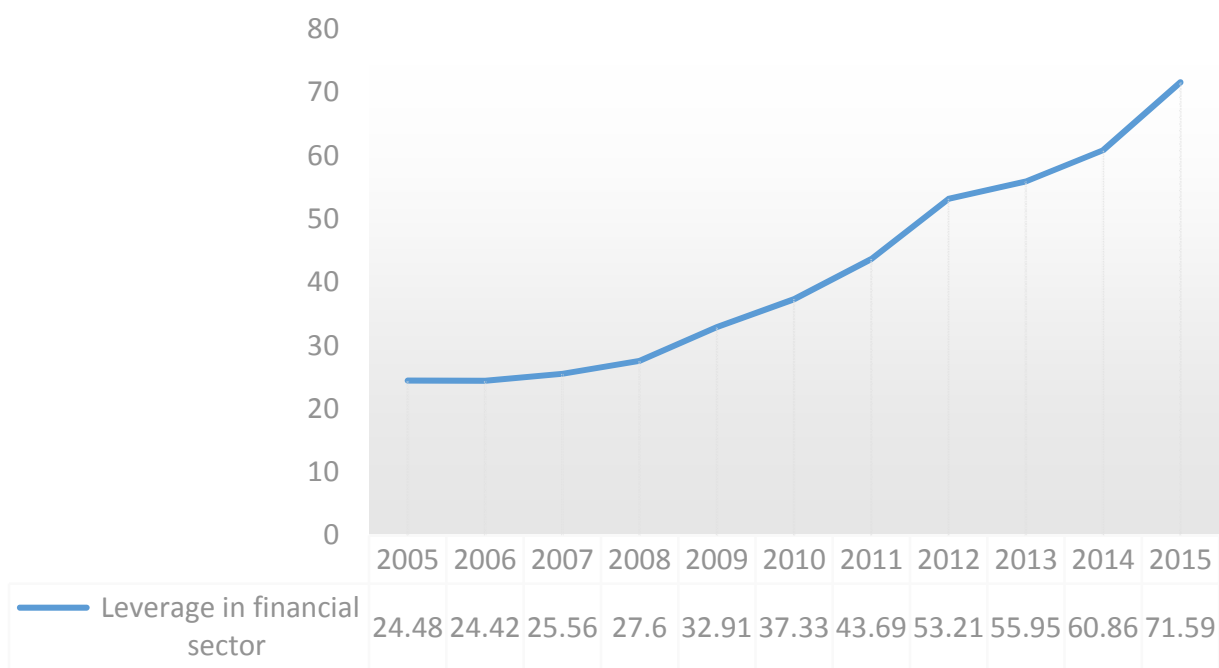

Figure 2. Leverage ratio of China's financial sector measured by McKinsey method (\%)

Since financial enterprises are special enterprises operating financial commodities and have the characteristics of high liability for operation, their liabilities constitute the assets of the non-financial sector. Therefore, in order to avoid repeated calculation, the debt statistics of the financial enterprise sector do not take into account the currency and deposits, and only use various bonds issued by the financial sector for accounting. As can be seen from figure 2, from 2005 to 2015, the debt rate of China's financial institutions showed a significant upward trend. The total debt of the financial enterprise sector increased from 45860.2 billion Yuan in 2005 to 49 trillion Yuan in 2015, an increase of 10.7 times in 11 years. The debt balance of financial institutions increased from $24.48 \%$ of GDP in 2005 to $71.59 \%$ in 2015 , up 47 percentage points in 11 years.

\subsection{Overall Leverage}

By summarizing the leverage ratio of the four sectors mentioned above, we can get that the total leverage ratio of the whole society in China in 2015 was $316.59 \%$ (245\% in the non-economic sector, $71.59 \%$ in the financial sector, and calculated by the McKinsey method).

Table 1. Comparison of economic debt structure of major economies in 2015 ( $\%$ of GDP)

\begin{tabular}{|c|c|c|c|c|}
\hline Countries & Government debt & Household debt & Non-financial corporate debt & Total debt ratio \\
\hline Japan & 234.0 & 65.0 & 101.0 & 400.0 \\
\hline Spain & 132.0 & 73.0 & 108.0 & 313.0 \\
\hline French & 104.0 & 56.0 & 121.0 & 281.0 \\
\hline Italy & 139.0 & 43.0 & 77.0 & 259.0 \\
\hline British & 92.0 & 86.0 & 74.0 & 252.0 \\
\hline China & 56.5 & 39.0 & 143.5 & 239.8 \\
\hline US & 89.0 & 77.0 & 67.0 & 233.0 \\
\hline Korea & 44.0 & 81.0 & 105.0 & 231.0 \\
\hline Canada & 70.0 & 92.0 & 60.0 & 221.0 \\
\hline Australia & 31.0 & 113.0 & 69.0 & 188.0 \\
\hline Germany & 80.0 & 54.0 & 54.0 & 128.0 \\
\hline Brazil & 65.0 & 25.0 & 38.0 & 120.0 \\
\hline India & 66.0 & 9.0 & 45.0 & \\
\hline
\end{tabular}

It can be seen from table 1 that the leverage ratio of China's real economy is close to that of the United States, Britain and other developed countries, and is at the middle level. However, the leverage ratio of non-financial enterprises is the highest, which reflects the severity of China's current overcapacity and the urgency of supply-side reform. The household sector has a low leverage ratio 
and the government sector has a mid-range leverage ratio. On the other hand, China's debt is mainly held by the domestic sector. China's savings rate is higher than the investment rate, and the national income and expenditure account is still in a double surplus. Therefore, the total leverage ratio of China's economy is relatively moderate, and the debt risk is generally controllable. It is worth paying attention to that, since the first half of 2016, the leverage ratio of China's residential sector has increased significantly, mainly in the field of real estate mortgage loans. In the context of increasing leverage, attention should be paid.

\section{Reasons for the Increase in China's Leverage Ratio}

China's non-financial sector leverage ratio has increased rapidly since 2008. The leverage ratio of the government sector and the household sector is from a low base. Although the growth is fast, it is still relatively low in terms of international comparison. The leverage ratio of non-financial enterprises is the highest in the leverage ratio of non-financial sectors, and the leverage ratio of nonfinancial enterprises is at the highest level from the international perspective. Therefore, it is necessary to focus on the rapid increase of leverage ratio of non-financial sectors and the high leverage of non-financial enterprises, and comprehensively analyze its causes. [7]. this part focuses on analyzing the causes of high leverage ratio of non-financial enterprises in combination with this situation, mainly including: abundant liquidity, debt-financed financing structure, and cyclical factors of economic development caused by changes in domestic and international political and economic environment.

\subsection{Political and Economic Environment Changes}

In order to cope with the impact of the 2008 global financial crisis on China's economy, China has introduced a lot of stimulus policies. By investing in infrastructure to boost domestic economic growth, China has entered a highly indebted period of leverage. The combination of internal and external factors leads to abundant domestic macro liquidity, providing superior monetary conditions for non-financial sector leverage. On the one hand, the rapid decline in GDP growth outpaced the decline in M2, the broad money supply, resulting in abundant macro liquidity. China's economic growth slowed down gradually from 2011. The annual GDP growth rate dropped from $10.8 \%$ in 2001-2007 to 8.4\% in 2008-2016, down 2.4 percentage points, and the M2 growth rate dropped from $16.7 \%$ to $16 \%$ in the same period, down 0.7 percentage points. [8]

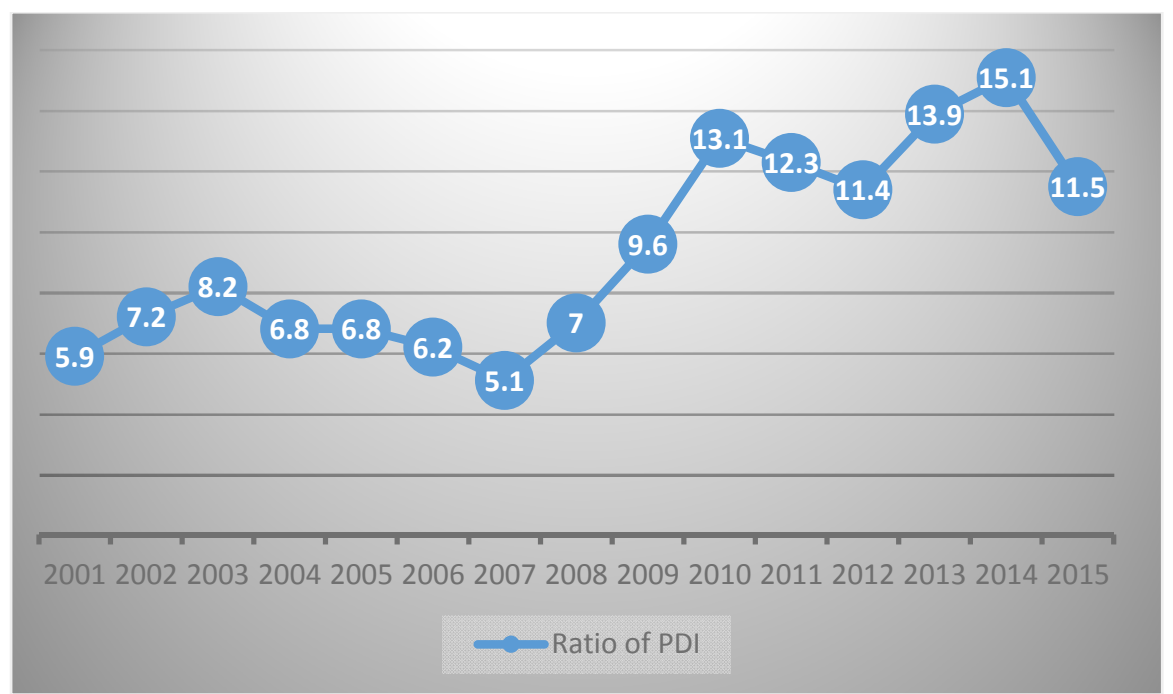

Figure 3. China's share of FDI in the world (us dollar) (Source: World Bank)

On the other hand, in order to cope with the international financial crisis, major economies in the world generally adopt loose monetary policies and there is relatively abundant liquidity around the world. Due to the obvious advantages of demographic dividend and superior economic development 
conditions, China has attracted a large number of international capital inflows, providing a stable source of capital for the domestic non-financial sector to increase leverage. According to the statistics of the World Bank, the annual proportion of FDI in China increased rapidly after 2008, with the annual average rising from $6.6 \%$ in 2001-2007 to $11.8 \%$ in 2008-2015 (Figure 3). From 2001 to 2016, China's actual FDI grew at an average annual rate of $6.1 \%$, and the absolute amount has exceeded us $\$ 100$ billion since 2010. Massive FDI has also boosted domestic liquidity and made it easier for the non-financial sector to increase leverage.

\subsection{Debt Financing Structure}

\subsubsection{Savings Rate}

Debt financing is the main financing structure in China, and indirect financing by Banks accounts for a high proportion of it, which increases the asset-liability ratio of non-financial entities, especially non-financial enterprises. The deeper reason is that: China's financial institutions are dominated by Banks; the social security system is not perfect and the residents have a strong preference for saving; the savings rate of the government and state-owned enterprises has been increasing. From 2001 to 2015, China's total national savings rate averaged $47 \%$ a year, compared with $24.3 \%$ for the same period, according to Wind data. The former was 22.7 percentage points higher than the latter. High leverage is also closely related to high savings rates, which are facilitated by adequate savings.

\subsubsection{Financing Method}

China has a single financing method and relies too much on indirect financing. In terms of the structure of social financing scale, the proportion of debt financing, such as bank loans, has been at a high level. In China's social financing scale, the proportion of bank loans in local and foreign currencies in new social financing scale decreased from $83.2 \%$ in 2005 to $66.7 \%$ in 2016 . Although the decline was obvious, the debt financing ratio of the whole society was over $90 \%$ for a long time. [9] In 2016, equity financing represented by equity financing in non-financial enterprises accounted for only $7 \%$ of social financing scale, which was lower than before.

\subsection{Cyclical Factors of Economic Development}

The leverage ratio of the non-financial sector represented by non-financial enterprises is countercyclical and tends to increase when economic growth slows down. Leverage, as a ratio indicator, increases when the numerator gets bigger or the denominator gets smaller. Since 2011, China's real economic benefits have continued to decline, which has also led to an increase in the leverage ratio of non-financial sectors. In the case of non-financial enterprises, the degree of leverage is negatively correlated with the economic cycle. When the economic growth rate is high, non-financial enterprises have a good market for their products, fast turnover of assets and strong profitability. They are not only easy to expand their assets, but also have less demand for bank loans. However, the decline in economic growth often leads to the decline in product sales, decreased asset turnover and reduced profitability of non-financial enterprises. It is not easy to expand the scale and requires more bank loans to maintain the operation, which leads to high leverage ratio. This means that from the perspective of macro-economy, the leverage ratio of economic growth in the upswing period is usually lower, while the leverage ratio increases when economic growth is in the downward channel.

\section{The Potential Risks of Increased Leverage}

\subsection{Potential Risks to the Government Sector}

Our government debt is mainly used for constructive or investment spending. In some public finance countries, such as the United States, social security, education, health, national defense and general public affairs are relatively high in debt funds, and economic construction, especially direct economic expenditures, are relatively low. Because of this, even though the debt of the Chinese government may be difficult to repay the principal and interest to some extent in the future, it can still be used for debt repayment by means of securitization or direct sale, which is also an advantage that 
some public finance countries do not have. From the perspective of international experience, there is no precedent for a government sovereign debt crisis caused by large-scale debt investment in infrastructure construction. Although China's overall government debt is under control, and the leverage ratio of the central government has been kept low, the leverage ratio of local governments has risen rapidly in recent years and accumulated large risks.

\subsection{Potential Risks in the Non-Financial Corporate Sector}

In the future, the risk hidden danger of China's non-financial corporate sector leverage mainly comes from two aspects. First, economic growth continues to slow down, enterprises are having difficulties in production and operation, and capital turnover is not smooth. In the future, China's nonfinancial enterprises should not take measures to reduce leverage blindly, but should focus on improving their operating efficiency and maintaining stable economic growth. Second, the potential risk impact of international capital flows. In the post-financial crisis period, emerging market countries will face a reduction in external demand. Once the international capital flows are reversed, liquidity risks and asset prices will be reduced, and corporate leverage will be increased.

\subsection{Potential Risks in the Residential Sector}

The risk hidden danger of household sector leverage rate mainly comes from two aspects. First, the downward trend in economic growth will affect people's employment and income. Second, there are risks in the real estate market. In recent years, China's real estate prices have risen rapidly, real estate has become an important asset for urban households. Once property prices fall, household leverage will rise sharply. According to the national bureau of statistics, personal mortgage loans totaled 1330.05 billion Yuan from January to July 2016, up 54.6\% from a year earlier. According to the internationally accepted saying, the ratio of house price to income is a reasonable range between 3 and 6 times, and it is obvious that many Chinese cities have deviated from this range.

\subsection{Potential Risks in the Financial Enterprise Sector}

At the current level of leverage, the risk hidden danger in the financial enterprise sector mainly comes from the real economy. Declining economic growth will lead to poor quality of credit assets, and there are risks and hidden dangers in government financing platforms and the real estate market, which will affect the quality of bank assets. Another important risk concern for the leverage of the financial sector comes from shadow Banks. The 2008 international financial crisis has shown that the risks of shadow banking are complex, covert, fragile, sudden and infectious, and easy to induce systemic risks. At present, China's financial regulatory authorities are taking active measures to control and defuse risks in the shadow banking system.

\section{Suggestions to Solve the Potential Risks of High Leverage in China}

The history of finance at home and abroad shows that behind the financial crisis is the deleveraging crisis, essentially the credit crisis. From the great depression in 1929 to the financial tsunami on Wall Street in 2008, as well as the drastic fluctuations of China's a-share market in 2007 and 2015, all these have demonstrated this. [10]At present, China has been in the upsurge period of financial cycle from the perspective of credit and real estate. In the process of deleveraging by non-financial enterprises, financial enterprises, local financing platforms and other departments, a series of credit shocks, such as credit default, increase of bad debts in Banks and reassessment of asset collateral, are likely to be brought. [11] - [13] In China's debt sector, the biggest problem is non-financial corporate debt. Debt rates in other sectors are relatively modest.

\subsection{Accelerate Supply-Side Reform}

The supply-side reform mainly involves overcapacity, large housing inventory and high debt. In order to solve this problem, we need to carry out the five tasks of capacity reduction, inventory reduction, leverage reduction, cost reduction and short selling. Since these debts are mainly in the 
corporate sector, especially the state-owned enterprises, the debt issue should be dealt with in close combination with some reform. In view of the fact that China's debt leverage varies from sector to sector, supply-side structural reform should be implemented.

\subsection{Deepening Reform of State-Owned Enterprises}

State-owned enterprises account for a large proportion of China's high leverage ratio in the nonfinancial enterprise sector. Deepening the reform of state-owned enterprises, enhancing the vitality of state-owned enterprises and reducing the leverage ratio of state-owned enterprises are urgent requirements to reduce the leverage ratio of non-financial enterprises. In September 2015, the state council issued the "guiding opinions on deepening the reform of state-owned enterprises", which is a programmatic document guiding and promoting the reform of state-owned enterprises in the new era. The central economic work conference in December 2016 stressed that the reform of mixed ownership is an important breakthrough for the reform of state-owned enterprises. In accordance with the requirements of improving governance, strengthening incentives, highlighting main industries and improving efficiency, substantial steps have been taken in the areas of electricity, oil, natural gas, railways, civil aviation, telecommunications and military industry.

\subsection{Standardize Tools and Paths for Leverage}

In the new normal period, the potential growth rate of the economy is still in a downward cycle. To stabilize growth demand, it is inevitable for the government to increase leverage. As the asset prices of government departments are high, the securitization of financing platforms can be promoted. At the same time, the government can issue more standardized bonds and give relatively easy interest rates.

\subsection{Improve the Direct Financing Mechanism}

Indirect financing led by Banks is one of the main reasons for the high leverage ratio of nonfinancial enterprises. Optimizing the capital structure of enterprises and increasing the proportion of equity financing direct financing are effective means to solve the high leverage ratio of enterprise departments. We should further accelerate the expansion of IPO capacity, deepen reform and improve the share transfer system for small and medium-sized enterprises across the country. Regional equity market will be incorporated into the multi-level capital market system to improve China's equity financing direct financing mechanism.

\section{References}

[1]. Ma Jian tang, Dong Xiao Jun, et al. China's leverage ratio and systemic financial risk prevention [J]. Finance and trade economics, 2016 (01): 5-21.

[2]. Lou Feeing. Current situation of leverage ratio of non-financial sectors and Suggestions for deleveraging [J]. Southwest finance, 2017 (07): 23-29.

[3]. Fan Luong. A study on the causes and countermeasures of China's high leverage [J]. Friends of accounting, 2017 (23): 72-73.

[4]. Tan Xiao fen, Yin Bijou. Leverage ratio of China's non-financial enterprises: status quo and countermeasures [J]. China foreign exchange, 2016 (11): 20-22.

[5]. Zhang Xiaoping. How to actively yet prudently deleverage [N]. Social science daily, 2017.

[6]. CF40 Research Group. Active or passive deleveraging [J]. China finance,2016(19):12-14.

[7]. Reinhart, CM. Reinhart, VR and Roof, KS (2012). "Debt Overhangs: Past and Present". NBER working paper,4(2). 
[8]. Cuero, C., Drumand, I., Lendvai, J., Pontus, P. and Raciborski, R (2014). "Private sector deleveraging in Europe". Economic Modelling,(44).pp.372-383.

[9]. Leaven, L. and Valencia, F (2012). "Systemic Banking Crises Database: An Update". IMF Working Paper, 61(2).

[10]. Tipper, A. and Borowiecki, KJ (2014). "A Leverage-Based Measure of Financial Instability". SsrnElectronic Journal, 1.

[11]. Adrian, T. \& Boyarchenko, N. (2015) "Interne-diary Leverage Cycles and Financial Stability”. FederalReserve Bank of New York Staff Reports, 567.

[12]. Bernanke, B. and Gentler, M (2000). "Monetary Policy and Asset Price Volatility". Mark Gentler, 84(9), pp.77-128.

[13]. Krugman, P (1991). "Increasing Returns and Economic Geography". Journal of Political Economy, 99(3), pp.483-499. 